Ryszard Vorbrich

ORCID: https://orcid.org/0000-0001-7310-9400

Uniwersytet Adama Mickiewicza w Poznaniu

Instytut Antropologii i Etnologii

\title{
Tidili Centre - stolica gminy. Embrion struktury miejskiej w środowisku wysokogórskim Maroka
}

\section{Tidili Center - the capital of a commune. An embryo of an urban structure in the high-mountain environment of Morocco}

\begin{abstract}
This study presents the history of the creation of a small settlement called the Tidili Center, forming a kind of "embryo" of the urban structure, in the heart of the High Atlas. The analysis presents the natural, historical and socio-political context accompanying the emergence of this micro-urban environment. The settlement was established in cruda radice in the traditional lands of the Ait Tidili tribe, and formally became the capital of the commune. By assuming many economic, social (administrative) and cultural functions, the settlement in question took the form of a heterogeneous local community and became an expression of changes that took place in this area over four decades, where until now a relatively closed and homogeneous local (sub-regional) community is included in a wider system national community.
\end{abstract}

Keywords: Maroc, Atlas, Berberes, Tidili, tribe, duar, urban structure, rural commune, long duration processes

Niniejsze opracowanie przedstawia historię powstania w ukrytej wśród szczytów Atlasu Wysokiego niewielkiej osady zwanej Tidili Centre, stanowiącej dziś rodzaj „embrionu” struktury urbanistycznej. Analiza, odwołująca się do koncepcji procesów długiego trwania, przedstawia kontekst przyrodniczy, historyczny i społeczno-polityczny towarzyszący powstawaniu tego mikromiejskiego środowiska. Osada powstała „na surowym korzeniu” na tradycyjnych ziemiach plemienia Ait Tidili, stając się formalnie stolicą gminy. Pełniąc wiele funkcji gospodarczych, społecznych (administracyjnych) i kulturalnych, omawiana osada tworzy ramy 
przestrzenne społeczności lokalnej o heterogenicznym charakterze. Jest też wyrazem zmian, jakie zaszły na tym obszarze na przestrzeni czterech dekad, gdzie dotychczas stosunkowo zamknięta i jednorodna lokalna (subregionalna) społeczność włączona została do szerszego systemu wspólnoty narodowej.

Słowa kluczowe: Maroko, Atlas, Berberowie, Tidili, plemię, duar, struktura miejska, gmina wiejska, procesy długiego trwania

Odebrano / Received: 20.03.2021

Zaakceptowano / Accepted: 05.10.2021

Celem niniejszego studium jest przedstawienie procesu powstawania protomiejskiej osady Tidili Centre ulokowanej w centrum masywu Atlasu Wysokiego w Maroku. Prowadzone przeze mnie w ciagu 30 lat badanie terenowe $\mathrm{w}$ tym regionie pozwoliły $\mathrm{mi}$ na zastosowanie metody antropologicznych badań nad procesami długiego trwania ${ }^{1}$, rekonstruującej okoliczności i etapy formowania się osady, reprezentującej typ mikro-urbanizacji, właściwy dla regionów górskich Maroka².

Starałem się ukazać, w jaki sposób warunki naturalne - typowa struktura długiego trwania oraz historycznie ukształtowane czynniki ekonomiczne, polityczne oraz kulturowe (etniczne) wpływały na strukturalną i funkcjonalną izolację oraz marginalizację omawianego subregionu i przetrwanie społeczeństwa o cechach plemiennych. Ukazując

1 W ujęciu antropologicznym koncepcja procesów długiego trwania różni się nieco od tej zaproponowanej przez nauki historyczne, zwłaszcza Fernanda Braudela, który operował stuleciami („historiami bardzo długiego trwania”), rzadziej dekadami (Braudel 1999: 49). W sytuacji społeczeństw niepiśmiennych (lub w znacznej części niepiśmiennych) brak źródeł pisanych ogranicza pole badawcze do jednego - dwóch pokoleń. Sięgnięcie dalej w przeszłość wymaga już zastosowania metod etnohistorii.

2 Brak miejsca nie pozwala mi tu rozwinąć szerzej kwestii metodologii i metodyki tych badań. Nadmienię jedynie, że przybrały one formę typowych dla antropologii (etnologii) badań terenowych. Objęły one sześć sezonów badawczych (1990,1995, 1997, 1998, 2013,2016). Moje pobyty, trwające od kilku tygodni do kilku miesięcy, realizowane były w różnych formułach organizacyjnych: jako stypendysty (tzw. postdoc) na Université Mohammed V w Rabacie, kierownika grantu badawczego KBN/NCN oraz kierownika projektów badawczo-edukacyjnych $\mathrm{z}$ polskimi studentami (finansowanych m.in. przez UAM w Poznaniu, Fundację Batorego lub Air Maroc). Dało mi to możliwość poznania życia mieszkańców doliny oraz pozyskania przychylności lokalnych władz. Badania terenowe rozłożone na dekady unaoczniło mi dynamikę zmian, jakie zaszły w badanym terenie w ciągu życia więcej niż jednego pokolenia, dało mi też dostęp do niepublikowanych danych urzędowych oraz zasobów pamięci najstarszych mieszkańców (w tym najstarszych stażem pracowników urzędu gminy). Pozyskana sieć kontaktów dała mi możliwość kontynuowania badań w latach późniejszych, także w formule zdalnej w czasach pandemii (2020/2021). W tym miejscu chciałbym podziękować wszystkim Ait Tidili za okazana mi pomoc i gościnę podczas kilku dekad mych badań. Nie sposób przywołać ich tu wszystkich z imienia. Jednak szczególnie wdzięczny jestem pani Fatimie Elyamal oraz panu Rachidowi Garoud, którzy umożliwili mi wgląd do oficjalnej dokumentacji gminy oraz wspomogli mnie zasobami swojej pamięci, sięgającej początków gminy Tidili. 
dynamikę ostatnich 100 lat $^{3}$, wskazuję, jak za sprawą zmiany okoliczności politycznych i ekonomicznych, w tym kontekście przystających do braudelowskiej koncepcji „wydarzenia”, następowało stopniowe otwieranie się doliny Tidili na świat zewnętrzny (struktury państwa i społeczeństwa typu narodowego), prowadzące do przekształcenia miejscowego, tradycyjnego modelu siedzisk ludzkich oraz form organizacji społecznej.

Tidili, a dokładniej Tidili Centre, to osada powstała „na surowym korzeniu” w ciągu ostatnich 40 lat w jednej z dolin Wysokiego Atlasu marokańskiego. W tym surowym i wymagającym środowisku naturalnym, podczas życia dwóch pokoleń uformowała się, praktycznie z „niczego”, stolica gminy wiejskiej. Dzisiaj stanowi ona swoisty „embrion” struktury miejskiej, $z$ wieloma funkcjami administracyjnymi, gospodarczymi, społecznymi i kulturowymi.

Dno doliny Tidili wznosi się na wysokość ok. 1900 m n.p.m. i otoczone jest szczytami sięgającymi niemal $4000 \mathrm{~m}$ n.p.m. Dolina leży na południowym skłonie masywu Atlasu Wysokiego, co przez wieki determinowało jej warunki naturalne, kondycję ekonomiczną, sytuację społeczną i etniczną oraz status polityczny'

Nieliczne przełęcze przecinające masyw Atlasu (położone na wysokości 2000-2400 m n.p.m.), zasypane śniegiem w porze zimowej, pozbawione były do pierwszych dekad XX wieku solidnych dróg, co powodowało sezonowe odcięcie prowincji presaharyjskich od politycznego i gospodarczego centrum kraju.

Do lat 20. XX wieku w Maroku zaznaczał się podział na dwie tradycyjne strefy: bled el makbzen oraz bled es siba. Bled el makbzen ${ }^{5}$ to kraj poddany władzy sułtana, czyli dosłownie „kraj rządowy”. Obejmował on głównie doliny położone na północny zachód od masywu Atlasu. Uznać go można za rdzeń państwa.

Bled es siba - dosłownie: „kraj lwa” - to kraj odrzucający polityczne zwierzchnictwo sułtana. Bardziej niż skromny aparat państwa nie mógł go efektywnie kontrolować ani eksploatować ${ }^{6}$, choć władza centralna wywierała tu swój wpływ ideologiczny, kulturowy, gospodarczy i polityczny. W regionie Tidili granica pomiędzy bled el makbzen i bled es siba miała dość trwały charakter i biegła wzdłuż grzbietów górskich, nieco na północ od omawianej doliny.

3 Na co pozwalały źródła zastane (opracowania historyczne odnoszące się głównie do epoki Protektoratu) oraz informacje „wywołane” z pamięci mieszkańców doliny.

4 Emberger 1955, Vorbrich 1996.

5 Etymologicznie termin wywodzi się od el makhzen - „magazyn”. W średniowieczu używano go w odniesieniu do kufra - skarbca sułtańskiego. $Z$ czasem pojęcie to zaczęto używać na określenie władzy centralnej. Współcześnie władzę centralną w Maroku określa się mianem „neomakhzenu” (Vorbrich 1996).

6 Namiastką aparatu fiskalnego Maroka przed kolonialnego były zbrojne wyprawy armii sułtańskiej (z suwerenem na czele), które przemierzały poszczególne prowincje bled es siba co kilka lat, łupiąc mieszkańców, zbierając daniny, pieniądze, konie oraz inne dobra. W ostatnich dekadach epoki przedkolonialnej takie wyprawy na tereny położone na południe od masywu Atlasu zdarzały się raz na pokolenie (Norman 1980-81). 
Pozwoliło to na zachowanie przez mieszkańcow doliny pewnej odrębności kulturowej i językowej. Przetrwała tu do dzisiaj kultura i język berberski. Jeszcze w 1990 roku, gdy zacząłem tu badania terenowe, miejscowe kobiety nie znały języka arabskiego. Znajomość tego języka wśród mężczyzn była, dzięki szkołom koranicznym, już lepsza, natomiast znajomość języka francuskiego była bliska zeru?

Do czasu objęcia Maroka francuskim protektoratem, ludzie z doliny Tidili, podobnie jak większość mieszkańców masywu Atlasu, funkcjonowali w ramach segmentarnej struktury plemiennej. Mówiąc w uproszczeniu, kluczowym ogniwem organizacji społecznej były struktury rodowe. Ujawniały się one w przestrzeni fizycznej pod postacią wydzielonych i ulokowanych w pewnym dystansie od siebie zgrupowanych zabudowań - czymś w rodzaju przysiółku lub wsi (o homogennym charakterze), zwanych tu duar. Taki tradycyjny układ organizacji przestrzeni reprezentuje zamknięty, plemienny model urbanistyczny, wyrażony między innymi ufortyfikowaną linią zewnętrznych zabudowań oraz wioskową cytadelą w centrum osady (fot. 1).

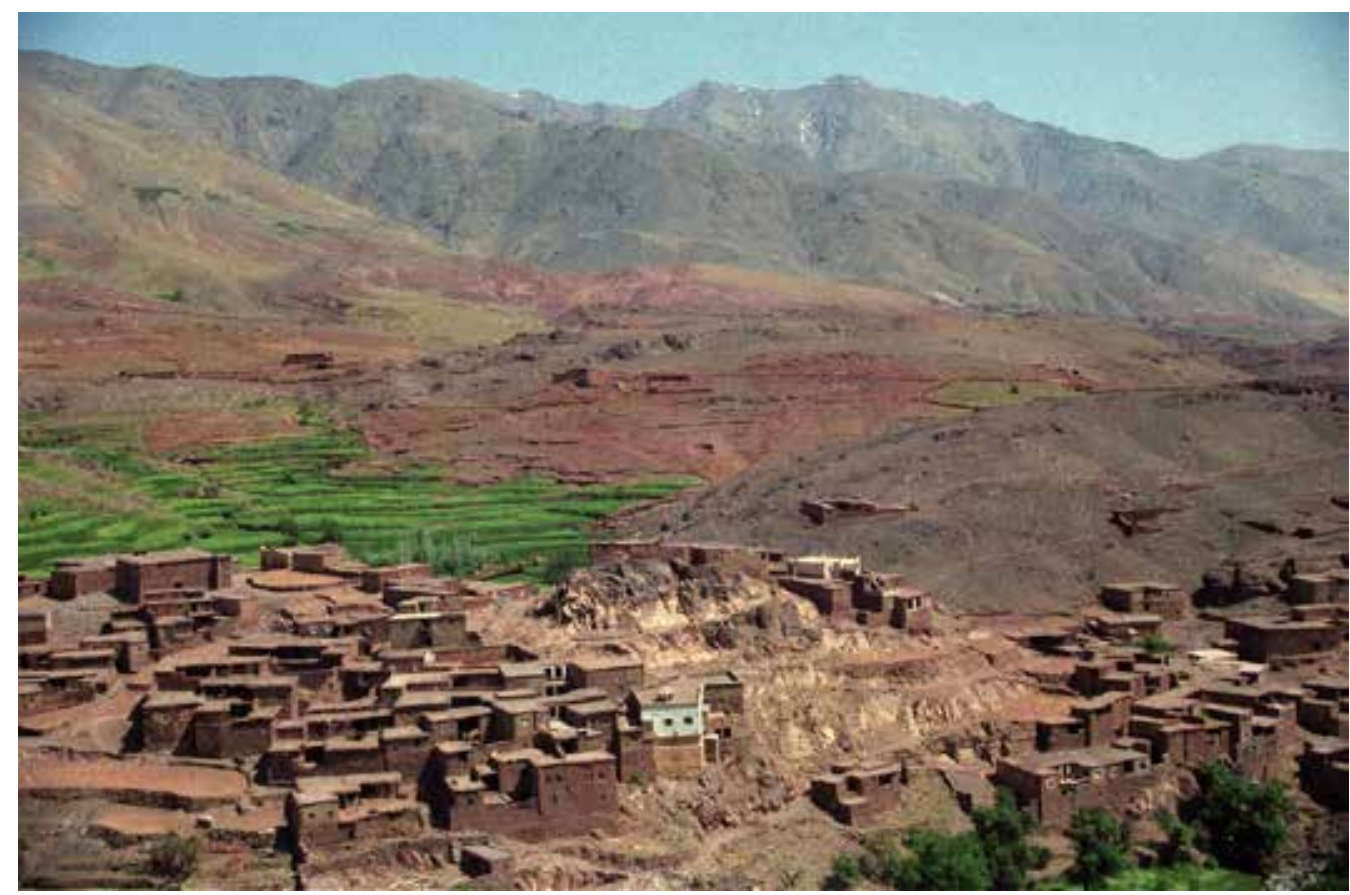

Fot. 1. Dolina Tidili. Na pierwszym planie duar Tammes - przykład tradycyjnego założenia urbanistycznego o homogennym charakterze w układzie fortyfikacyjnym, w tle Adrar Tidili (3915 m n.p.m.), fot. R. Vorbrich 1990

7 Wskaźnik analfabetyzmu utrzymuje się w gminie do dzisiaj na wysokim poziomie - 58\% (kobiety 73\%, mężczyźni 40\%), przy średniej krajowej - 38.5\% (Carte d'Identitie...,Alphabetisation au Maroc...) 
Kilka duarów (obejmujących po kilkanaście - kilkadziesiąt rodzin) tworzyło tzw. taqbilt, zwany w literaturze etnologicznej frakcją plemienia. Członków taqbiltu (1000-2000 osób) łączyła ideologia pokrewieństwa (często fikcyjnego), wyrażana w etnonimie $^{8}$, a zwłaszcza wspólnie opanowana i zagospodarowana przestrzeń (sieć tarasów uprawnych, a zwłaszcza sieć kanałów irygacyjnych oraz wspólnotowe pastwiska). W ten sposób taqbilty tworzyły, względnie samowystarczalną, wspólnotę ziemi, wody i pracy9 .

Taqbilty łączyły się w jednostki taksonomiczne wyższego rzędu zwane qbila - „plemię". Istota qbila była i jest trudna do zdefiniowania. Posiadało ono, co prawda wspólne terytorium, ale jego granice nie były z reguły ściśle ustalone. Takie plemię określić można mianem „górskiej republiki”. Plemię posiadało władzę ustawodawczą - zgromadzenie starszyzny rodowej - ḋ̇emaa i mianowanego przez nią na trwającą od roku do dwóch lat kadencję przewodniczącego - amghara. Wśród czynników integrujących qbila wymienić można jeszcze świadomość wspólnej historii, tradycji, w tym mitycznego przodka i powiązany z nim etnonim (w naszym przypadku - Ait Tidili) oraz peryferyjne (wysokogórskie) pastwiska komunalne, świętego patrona, flagę plemienną, a zwłaszcza plemienny targ ${ }^{10}$.

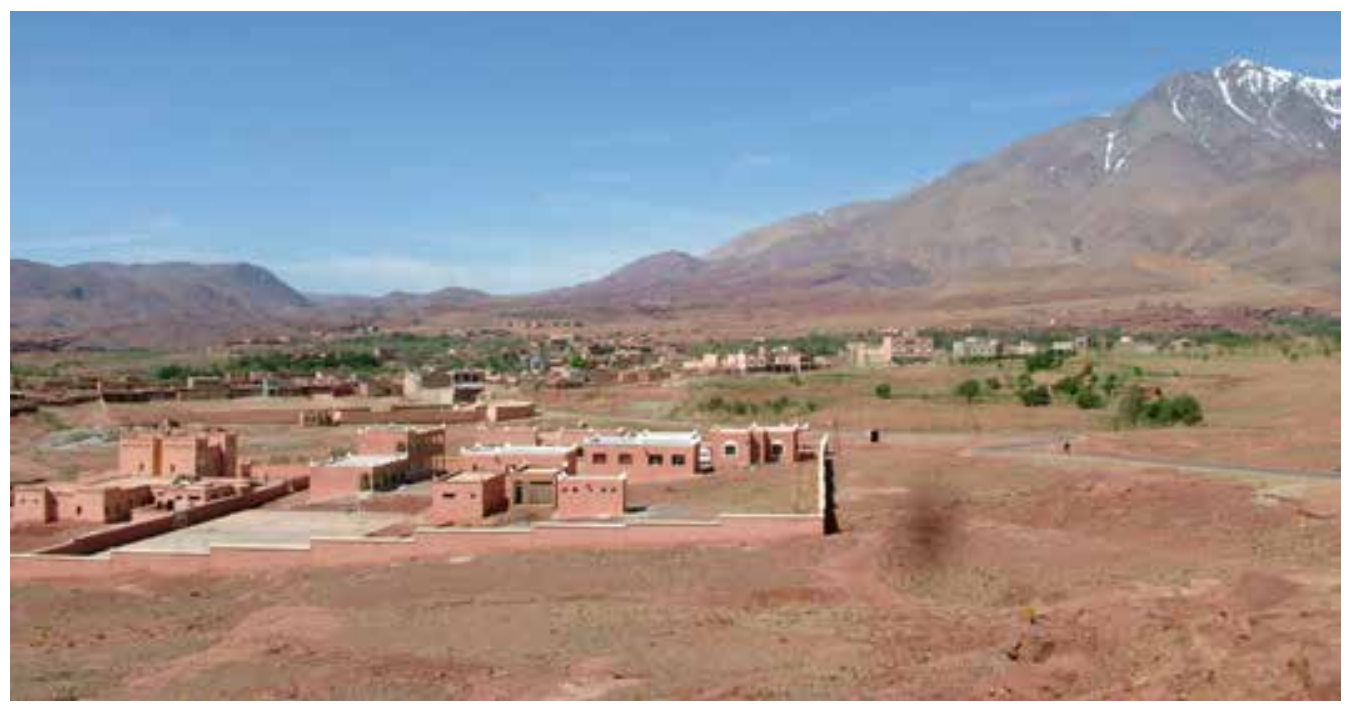

Fot. 2. Tidili Centre - przykład otwartego założenia urbanistycznego o charakterze administracyjno-handlowo-usługowym, na pierwszym planie budynki college'u, fot. R. Vorbrich 2016

\footnotetext{
${ }^{8}$ Etnonimy berberskich segmentów plemiennych składały się z dwóch członów; Ait - „synowie” i rdzenia odnoszącego się do imienia „przodka” lub częściej do cech miejscowego środowiska naturalnego. Na przykład nazwa Tidili wywodzi się berberskiego tadella oznaczającego zalesiony obszar.

${ }^{9}$ Vorbrich 1996.

${ }^{10}$ Vorbrich 1996.
} 
Cotygodniowy targ należy uznać za kluczową instytucję integrującą członków plemienia, a zarazem instytucję umożliwiającą kontakt z szerszym światem. Tworzył on przestrzeń, wokół której skupiały się najważniejsze funkcje oraz instytucje qbila. Plac targowy, targ - suq - był miejscem neutralnym, gdzie członkowie rodów ogarniętych wendetą spotykali się w pokoju. Stanowił miejsce pod ochroną sakralną - horm ${ }^{11}$, przestrzeń eksterytorialną, wyjętą spod jurysdykcji poszczególnych taqbiltów.

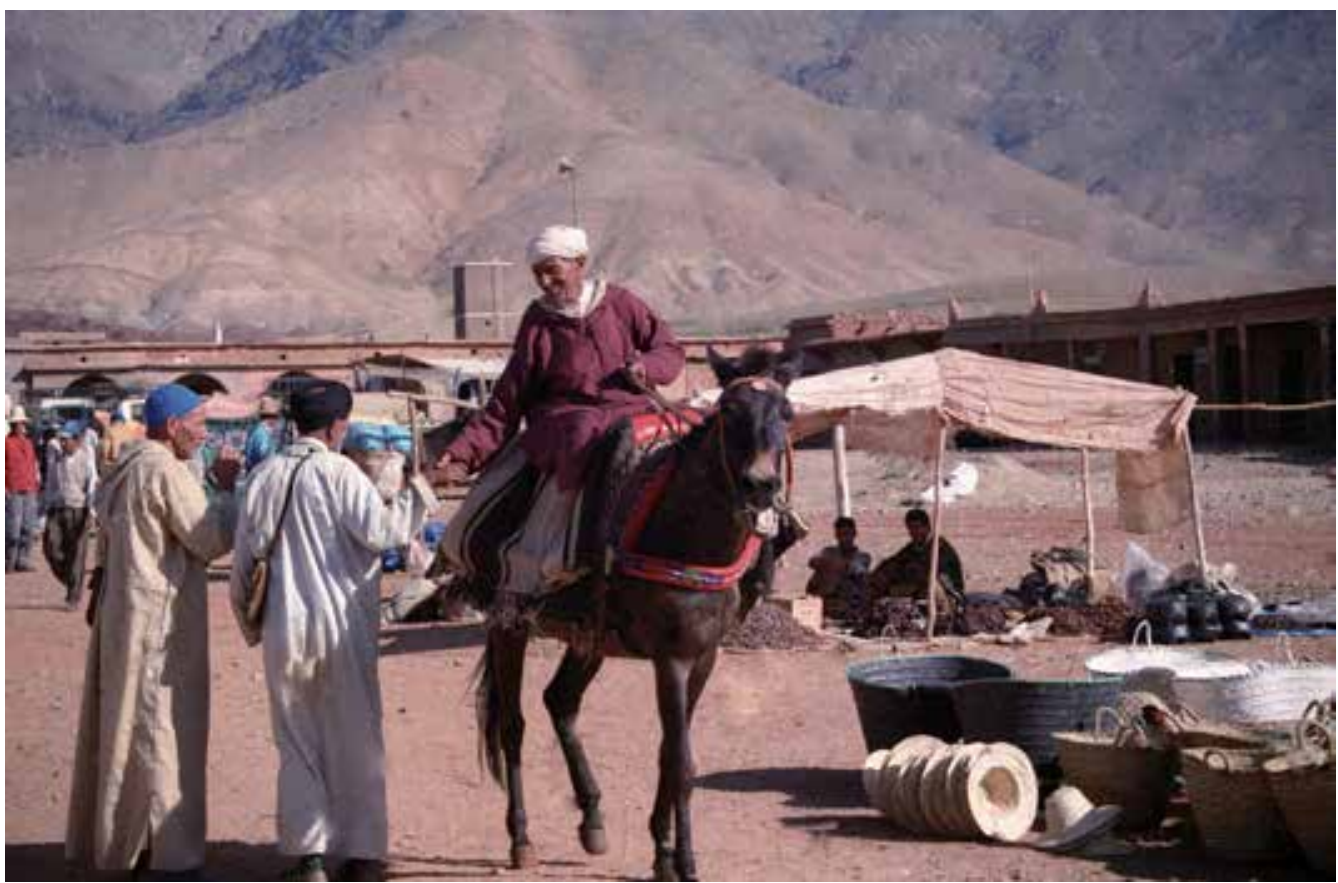

Fot. 3. Plac targowy Souk el Had. Brak budynków powstałych w następnych dekadach, fot. R. Vorbrich 1990

Przez stulecia masyw Wysokiego Atlasu, będący głównie regionem rolniczym, pozostawał na marginesie procesów urbanizacyjnych kraju. Atutem gór, były ukryte wśród skał złoża minerałów, zwłaszcza rud metali. Od wieków średnich rozwinęły się tu ośrodki górnictwa, miedzi, ołowiu, srebra i żelaza, ukierunkowane nie tylko na obsługę dolin atlantyckich, ale także na handel transsaharyjski (Dziubiński 1983: 86). Takimi zasobami naturalnymi dysponowały także okolice doliny Tidili. Poświadcza to między innymi miejscowa toponimia, na przykład takie nazwy, jak Bou Tazoult, Tazoulte-n-Oumradou (tazult - berb. „ołów”). Wraz z nastaniem epoki kolonialnej (a nawet o dekady

${ }^{11}$ Za naruszenie „pokoju” w przestrzeni horm groziły sankcje sakralne i drakońskie kary przewidziane przez prawo zwyczajowe (Benet 1957:198-208). 
wcześniej) oraz towarzyszącemu jej otwarciu kraju na Europę, napływowi importowanych towarów przemysłowych, a zarazem upadkowi handlu transsaharyjskiego, ośrodek ciężkości gospodarki marokańskiej przesunął się jeszcze bardziej ku północy, ku wybrzeżu atlantyckiemu. Od początku XX wieku, wraz z utratą niepodległości politycznej przez Maroko, spolaryzowany rozwój gospodarczy i społeczny kraju wzmocnił marginalizację regionów górskich. Nastąpił upadek ośrodków wydobywczych, a w ślad za tym uwiąd ośrodków protomiejskich masywu Atlasu.

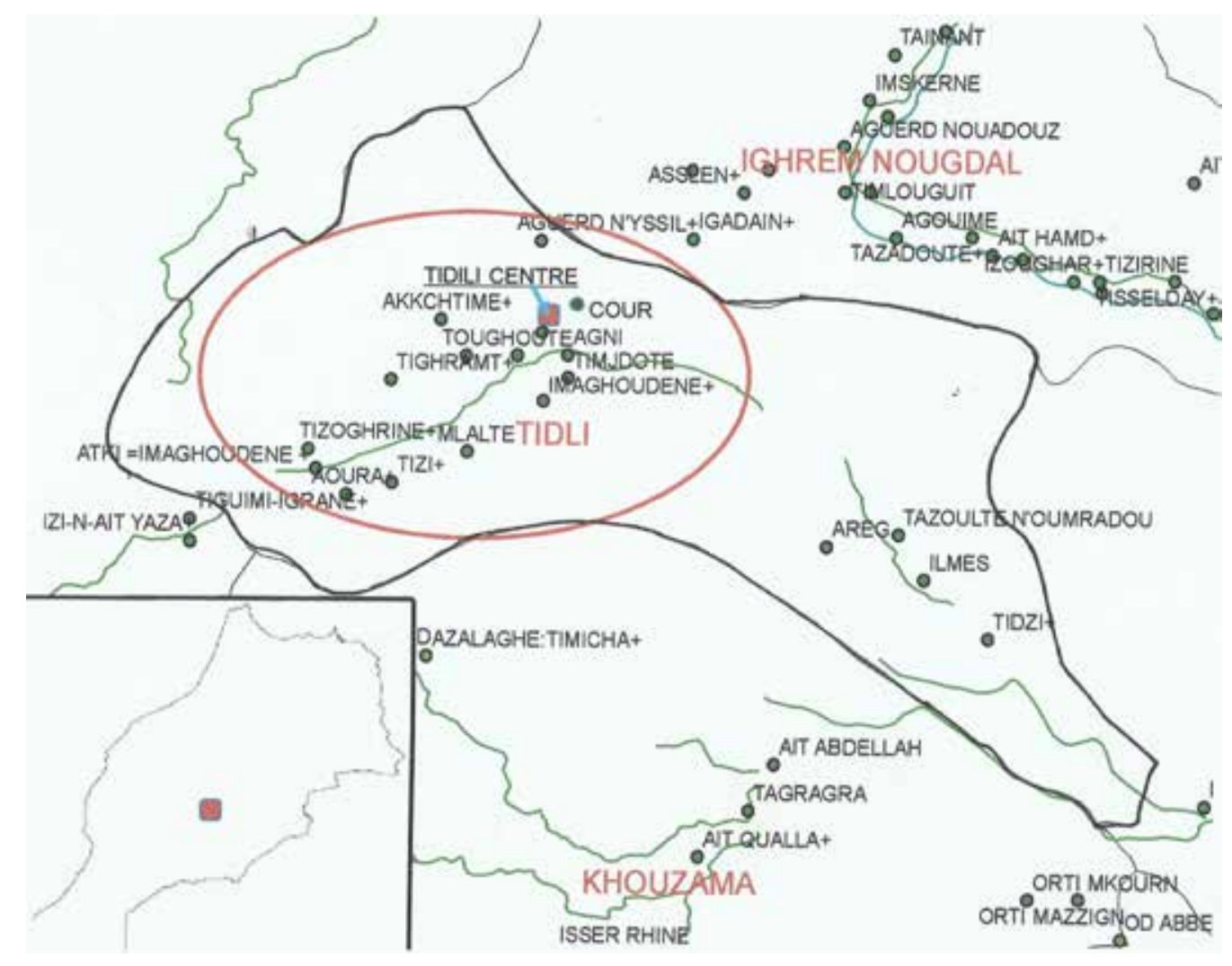

Fot. 4. Plan gminy Tidili, na podstawie: Carte d'Identité ...

Legenda: linia czarna - granice gminy Tidili, linia czerwona - przybliżone granice plemienia Ait Tidili

W tym samym czasie, w latach 20. XX wieku, miała miejsce utrata niezależności politycznej górskich wspólnot plemiennych. Było to efektem pacyfikacji regionów górskich, dokonanej rękoma wojsk francuskich (i marokańskich oddziałów pomocniczych), działających nominalnie w imieniu sułtana. Regiony dawnego bled es siba zostały ostatecznie i na trwałe włączone w struktury państwa marokańskiego, będącego francuskim protektoratem. „Górskie republiki” były wówczas kontrolowane i przez oficerów Biura do Spraw Tubylczych (Bureaux des Affaires Indigènes). Kadra Biura (około 300 osób) 
tworzyła namiastkę administracji terenowej (Gandini 2016). Ze względu na szczupłość kadr, pełnili oni nie tyle funkcje administracyjne, co raczej rozpoznawczo-pacyfikacyj$n \mathrm{e}^{12}$. W praktyce wspólnoty górali żyły własnym życiem, regulowanym przez tradycyjne ḋ்emaa, tolerowane przez Francuzów jako forma rządów pośrednich ${ }^{13}$.

Jednak to w okresie Protektoratu dolinę Tidili włączono w sieć dróg krajowych (i lokalnych). Zaledwie o 30 kilometrów (w linii prostej) od terytorium plemienia Ait Tidili, poprzez przełącz Tizi-n-Tichka (2260 m n.p.m.), wytyczono w latach 20. XX wieku strategiczną drogą przecinającą masyw Atlasu Wysokiego. Od niej odchodziła, licząca $26 \mathrm{~km}$, gruntowa droga do plemiennego targu - w okolicach osady Sour, od lat 50. XX wieku dostępna dla samochodów terenowych. Dla górali oznaczało to możliwość łatwiejszego kontaktu ze światem zewnętrznym.

W przypadku plemienia Ait Tidili nadzór szczątkowej, należałoby powiedzieć „objazdowej” administracji był dość słaby. W ostatnich latach Protektoratu, podjęto próby stworzenia struktur administracyjnych na poziomie „gminy”. Na przełomie 1951 i 1952 roku powołano między innymi do życia omawianą tu gminę Tidili. W praktyce była to jednak jednostka organizacji terytorialnej o charakterze nominalnym ${ }^{14}$. Formalnie stolicą gminy była największa wieś w okolicy - duar Sour. W tym czasie osada ta miała istotne znaczenie gospodarcze, była bowiem siedzibą gminy żydowskiej ${ }^{15}$. Po wyjeździe wszystkich Żydów na przełomie lat 50. i 60., znaczenie Sour podupadło. Pozostała już tylko zwykłą osadą rolniczą.

Zbiegło się to z uzyskaniem niepodległości przez królestwo Maroka. Jednym z najpilniejszych zadań władz centralnych królestwa - neomakbzenu - było wówczas pełne zintegrowanie regionów górskich $\mathrm{z}$ resztą kraju oraz rzeczywiste podporządkowanie ich w wymiarze politycznym i ekonomicznym. Droga do tego celu wiodła poprzez zbudowanie nowoczesnej administracji. Po 1956 roku zlikwidowano Biuro do Spraw Tubylczych i podlegle im dizemaa. Kraj podzielono na prowincje, regiony, okręgi, gminy (wiejskie i miejskie) oraz sekcje gmin ${ }^{16}$.

${ }^{12}$ Najbliższa placówka Biura do Spraw Tubylczych znajdowała się w Ouarzazate, odległym od doliny Tidili o około $100 \mathrm{~km}$.

${ }^{13}$ Należy w tym miejscu zaznaczyć, że względna swoboda pozostawiona góralom związana była z tzw. „polityką berberską" Protektoratu, w ramach której Francuzi dążyli do zmiany statusu prawnego i kulturowego marokańskich Berberów w celu oddzielenia ich od marokańskich Arabów (Vorbrich 1996, 2020).

${ }^{14}$ Nowo erygowana gmina zarządzana była praktycznie z odległego o $93 \mathrm{~km}$ Ouarzazate, a od $1963 \mathrm{roku}$ $z$ oddalonego o $36 \mathrm{~km}$ Irghem Ougdal (badania własne).

${ }^{15}$ Żydzi marokańscy znajdowali się pod zwyczajową ochroną sułtana. Gminy żydowskie występowały głównie w większych miastach. Jednak także wśród górskich plemion spotkać można było niewielkie liczebnie osady (gminy) żydowskie, wzbogacające paletę zawodów ludności wiejskiej. Trudnili się oni rzemiosłem i handlem. Zapewniali usługi parabankowe. W latach 50.XX wieku liczbę marokańskich Żydów szacowano na 270 tysięcy. Na przełomie lat 50. i 60. XX wieku, w wyniku zakrojonej na szeroką skalę akcji przesiedleńczej, większość Żydów wyemigrowała do Izraela (Adam 1968, Toledano 1989).

${ }^{16}$ Ashford 1961. 
W myśl polityki unifikacji kulturowej kraju, budowy nowoczesnego „narodu marokańskiego”, naczelnym imperatywem określającym kształt jednostek administracyjnych było zatarcie podziałów etnicznych oraz śladów struktur kolonialnych. Granice tworzonych jednostek administracyjnych odwoływały się zatem raczej do faktów geograficznych niż do etnicznych. O ile było to łatwiejsze na poziomie prowincji i okręgów, to okazało się trudniejsze na poziomie gmin wiejskich, zwłaszcza na terenach górskich, gdzie granice plemion wpisywały się w struktury fizyczne, a granice plemion przebiegały graniami szczytów górskich. Powołana dla wyznaczenia granic gmin wiejskich, specjalna objazdowa komisja rządowa, posługiwała się oficjalnym sloganem zniszczenia plemiennej struktury. Jak jednak okazało się w praktyce, było to często niewykonalne. Zgodnie z instrukcją Ministerstwa Spraw Wewnętrznych, „nadzwyczaj ważna operacja techniczna reformowania gmin polega na dzieleniu plemion na jednostki, które będą ekonomicznie samowystarczalne, politycznie spójne i etnicznie zharmonizowane"17. W efekcie kształt wielu gmin wiejskich odtwarzał wyraźnie tradycyjne granice plemienne ${ }^{18}$.

W ten sposób ziemie plemienia Ait Tidili, wpisujące się idealnie w krajobraz, a zarazem eksploatowane przez samowystarczalną gospodarczo wspólnotę subregionalną ${ }^{19}$, mającą własne tradycje władzy przedstawicielskiej, znalazły się w granicach jednej gminy. Gmina zwana była początkowo Commune rurale Douar Sour (Şour), później także gminą Souk el Had (od nazwy cotygodniowego targu - ar. had - niedziela). Od 1992 roku gmina nosi oficjalną nazwę Commune rurale Tidili ${ }^{20}$ - znajduje się $\mathrm{w}$ okręgu Amerzgane, prowincji Ouarzazate.

W 1974 roku podjęto decyzję przeniesienia siedziby administracji gminy do miejsca położonego o $1500 \mathrm{~m}$ od duaru Sour, w przestrzeni wówczas „pustej” z perspektywy urbanistycznej. Rozpoczęła się budowa materialnej infrastruktury gminy. W roku 1976 ostatecznie wytyczono tu nowy plac targowy, wokół którego wyrosła, na „surowym korzeniu" protomiejska osada zwana dzisiaj Tidili Centre ${ }^{21}$.

\footnotetext{
${ }^{17}$ Ashford 1961: 357.

${ }^{18}$ Struktury plemienne okazały się zatem żywotniejsze, niż sądzili ideolodzy modernizacji kraju. Względy ekologiczne i ekonomiczne zdecydowały, iż z 726 gmin wiejskich Maroka ponad 50\% nawiązuje do tradycyjnych struktur plemiennych i granic ḋ̇emaa z epoki Protektoratu (Zartman 1964).

${ }^{19}$ Dzięki wspólnym panowaniu nad komplementarnymi typami środowiska naturalnego.

${ }^{20}$ Co było nawiązaniem do tradycyjnej etymologii plemiennej i stanowiło praktyczny wyraz rewitalizacji i legitymizacji kultury berberskiej w Maroku. Zarazem stanowiło dobrą ilustrację szerszej polityki terytorialnej państwa i kompromisów w ramach produkcji toponimicznej w tym kraju (Boujrouf, Hassani 2008).

${ }^{21}$ Kwestia wyłaniania się struktur mikro-urbanistycznych $\mathrm{z}$ tradycyjnych osad wiejskich była przedmiotem zainteresowania badaczy marokańskich (a wcześniej jeszcze francuskich doby Prorektoratu). O ile badacze francuscy (Despois, Noin 1972; Troin 1975) koncentrowali się na procesie przekształcania się wiejskich targów w ,embriony miasta”, jako forpoczty gospodarki towarowej, o tyle współcześni antropolodzy i geografowie marokańscy skupiają się raczej na
} 
W kolejnych latach plac targowy o powierzchni ok. $8000 \mathrm{~m}^{2}$ został otoczony z czterech stron linią parterowych (niekiedy dwukondygnacyjnych) budynków, mieszczących sklepy, magazyny i warsztaty usługowe, herbaciarnie i jadłodajnie (fot. 3,5$)$.

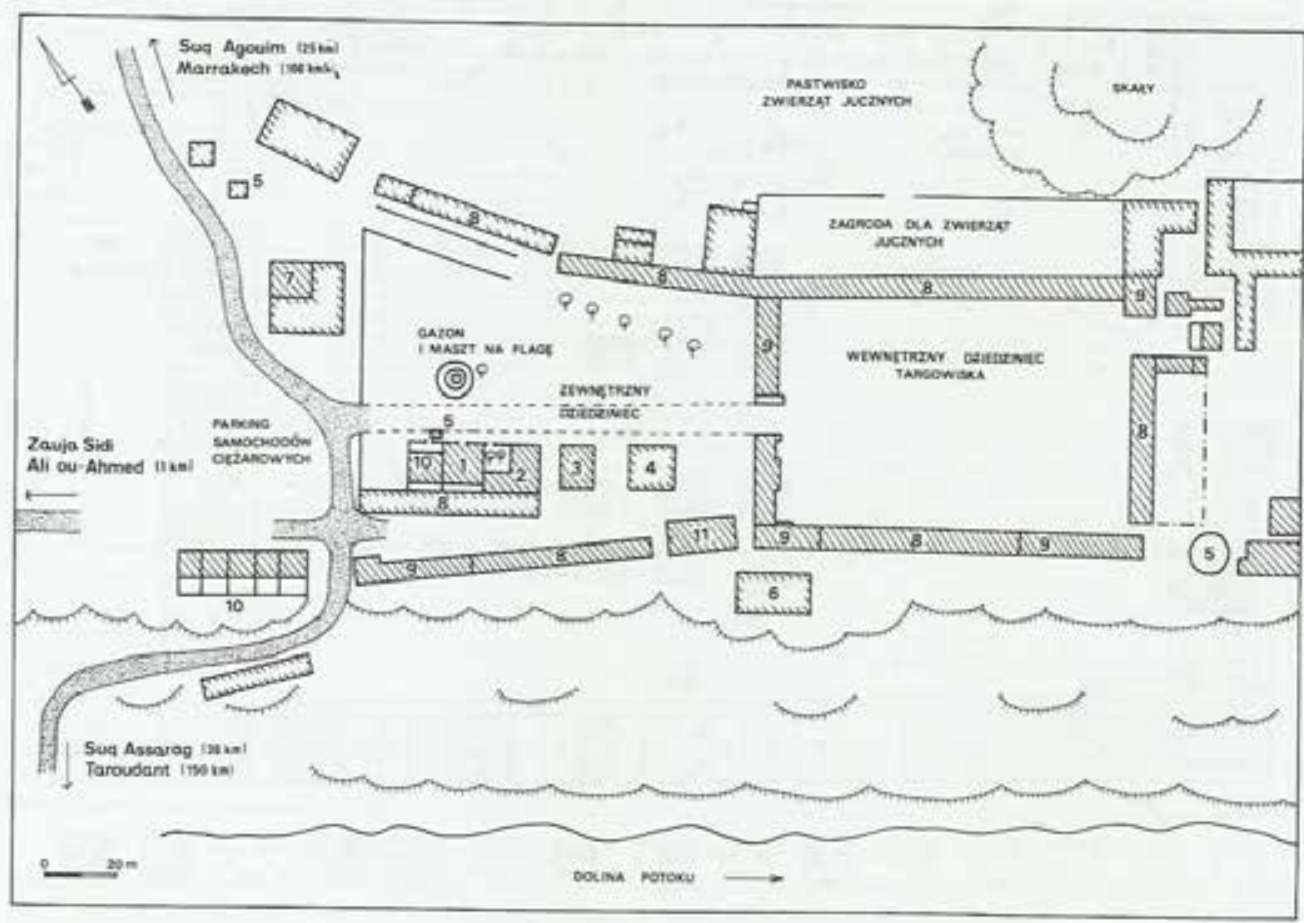

Fot. 5. Schematyczny plan placu targowego Souk el Had z przylegającymi zabudowaniami. Stan z 1995 roku, zaczyn osady Tidili Centre, rys. R. Vorbrich

Legenda: 1 - urząd gminy, 2 - poczta; 3 - ośrodek zdrowia, 4 - przedszkole, 5 - wieża ciśnień; generator prądu; 7 - piekarnia i łaźnia, 8 - sklepy, warsztaty, magazyny, 9 - gospody i herbaciarnie, 10 - domy urzędników, 11 - magazyn spółdzielni. Linią przerywaną zakreślono budynki powstałe w okresie 1991-1994

Jeszcze w latach 90. wszystkie te przybytki ożywiały się jedynie w dzień targowy, gdy przybywali kupcy z ośrodków miejskich i okolicznych gmin. $Z$ czasem do kwadratu

relacjach łączących zjawisko migracji (i związanych z nim przepływów finansowych - „lokowanych w kamieniu") z przemianą siedlisk wiejskich w osady o cechach miejskich oraz na ich dostosowaniu strukturalnym i funkcjonalnym do importowanych standardów (Berriane 1997; Ait Hamza 2002). Na obszarach wysyłających migrantów w całym Maroku ta gorączka budowlana przekształciła niektóre wioski w miasta (Fadloullah i in. 2000). Z kolei powstawanie nowych struktur miejskich przekłada się w Maroku na spadek dynamiki demograficznej większych aglomeracji, w tym zwłaszcza Casablanki (Schafar, Nassori 2016). 
placu targowego dobudowano półotwarty dziedziniec, tworzony przez parterowe budynki mieszczące także magazyny i sklepy ${ }^{22}$. W przestrzeni zewnętrznego dziedzińca wybudowano na przełomie lat 70. i 80. szereg niewielkich budynków użyteczności publicznej: urząd gminy, ośrodek zdrowia (z felczerem), przedszkole (dla dzieci funkcjonariuszy gminy), urząd pocztowy oraz skromny dom mieszkalny dla pracowników gminy. Całość uzupełniały zagrody dla jucznych mułów oraz bydła (opodal ubojni zwierząt), a także dwie wieże ciśnień, budynki mieszczące generator prądu (włączany okazyjnie dla ładowania akumulatorów) lub piekarnię połączoną z łaźnią.

W połowie lat 80., już poza dziedzińcem zewnętrznym, wybudowano pięć, na owe czasy nowoczesnych, parterowych domów dla pracowników gminy (zob. il. 5) ${ }^{23}$. Budynki te, ich lokalizacja oraz standard, wyznaczyły dalszy rozwój aglomeracji, która rozszerzyła się w latach 90. XX wieku na północ i północny zachód od placu targowego. Rozwój aglomeracji uległ zintensyfikowaniu na przełomie XX i XXI wieku, obejmując kilkadziesiąt parterowych (lub dwu- trzykondygnacyjnych) budynków w nieregularnym układzie ulicowym. W ten sposób powstała osada nawiązująca do nowego na tym terenie otwartego modelu urbanistycznego (fot. 2,6).

Wśród nowych budynków są głównie takie, które wyznaczają „miejskie” funkcje osady: nowoczesny urząd gminy, gminny ośrodek zdrowia z izbą porodową, szkoła ponadpodstawowa (college), z internatem dla uczniów, meczet, dwie kawiarnie (herbaciarnie) oraz gospoda. Obecnie (2020) w Tidili Centre - według danych urzędu gminy - funkcjonuje 200 (!) sklepów (boutiques), zapewniających w ciągu tygodnia (nie tylko w dzień targowy) szeroką gamę towarów. W miejscowej ofercie handlowej odnaleźć można głównie obuwie i odzież (także z wyborem sukni ślubnych, co uważa się tu za „towar miejski”), kosmetyki, galanterię przemysłową, tanią elektronikę, przybory szkolne, literaturę religijną i świecką, części zamienne do samochodów i gospodarstwa domowego. W otoczeniu sklepów znaleźć można dwie nowe, nowoczesne piekarnie oraz liczne warsztaty - stolarskie (produkcja mebli) i ślusarskie (produkcja żelaznych płotów i bram) oraz krawieckie. Wśród tego bogatego wyboru dóbr i usług nie brakuje także apteki (Pharmacie Tidili) (il. 9), punktów telefonii komórkowej oraz usług parabankowych.

Plany rozwojowe aglomeracji Tidili Centre ${ }^{24}$, kładą nacisk na rozszerzenie dostępu do infrastruktury i podstawowych usług społecznych, takich jak ochrona zdrowia

${ }^{22}$ Zabudowania placu targowego nie są własnością kupców, lecz gminy. Są one udostępniane za drobną opłatą.

${ }^{23}$ Jeden z nich służył jako „dom gościnny” dla funkcjonariuszy publicznych (agronomów itp.) wizytujących gminę. W roku 1990 został on przydzielony na kilka miesięcy autorowi niniejszego studium.

${ }^{24}$ Plan powstał w 2010/11 roku, dzięki wsparciu Ministerstwa Planu oraz Narodowej Inicjatywy na rzecz Rozwoju Ludzkiego (l'Initiative Nationale pour le Développement Humain-INDH), dysponującej miliardowym funduszem. Ogłoszona w drugą rocznicę krwawych zamachów bombowych w Casablance (w 2003 roku) inicjatywa INDH ma na celu poprawienie jakości życia Marokańczyków w obszarach 


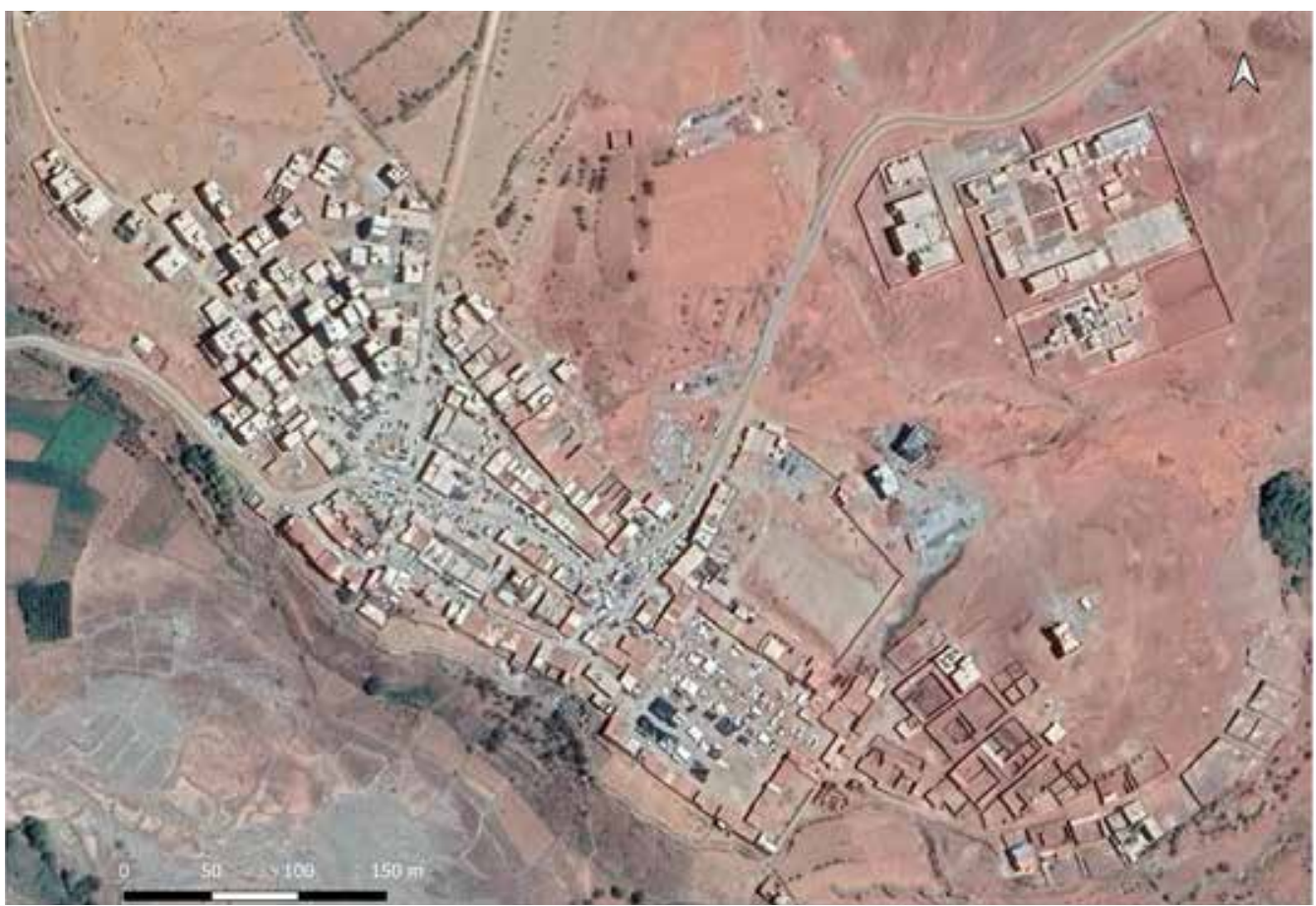

Fot. 6. Tidili Centre. Zdjęcie satelitarne, Google Earth, 16.08.2020

(zatrudnienie lekarza) i edukacja, udostępnienie „uzbrojonych” terenów pod zabudowę mieszkalną, wody, energii elektrycznej, kanalizacji, a także budowę dróg, centrów młodzieżowych i obiektów kulturalnych i sportowych. Plan wyznacza przestrzenie rozbudowy omawianej aglomeracji o nowe dzielnice oraz kierunki uzupełnienia infrastruktury instytucjonalnej, o specjalistyczne agendy państwa, takie jak liceum, posterunek policji oraz urząd pocztowy (fot. 7).

Infrastrukturę materialną gminy uzupełnia, wybudowana w 2011 roku, droga asfaltowa $(26 \mathrm{~km})$, dająca bezpieczne (wcześniej droga gruntowa dostępna była w sezonie jesienno-zimowym jedynie dla samochodów terenowych) połączenie ze strategiczną, transatlasyjską szosą (Ouarzazate - Marrakesz). Powstanie solidnego połączenia drogowego dało impuls do dynamicznego rozwoju motoryzacji. Do osady, dla której jeszcze na początku lat 90. XX wieku jedynym połączeniem ze światem zewnętrznym (oprócz zwierząt jucznych) był samochód ciężarowy docierający tu z zaopatrzeniem raz w tygodniu, obecnie kursują codziennie tzw. grand taxi. Zaś w dniu targowym ulice i place zapełniają dziesiątki (ponad sto) samochodów osobowych i ciężarowych, podczas gdy w zagrodzie dla jucznych mułów dostrzec można zaledwie pojedyncze zwierzęta (fot. 6).

niedorozwoju, a przez to zapobiegać migracji do miast i powstawaniu warstwy zdeprywowanych mieszkańców biednych dzielnic wielkich aglomeracji (Vorbrich 2015). 


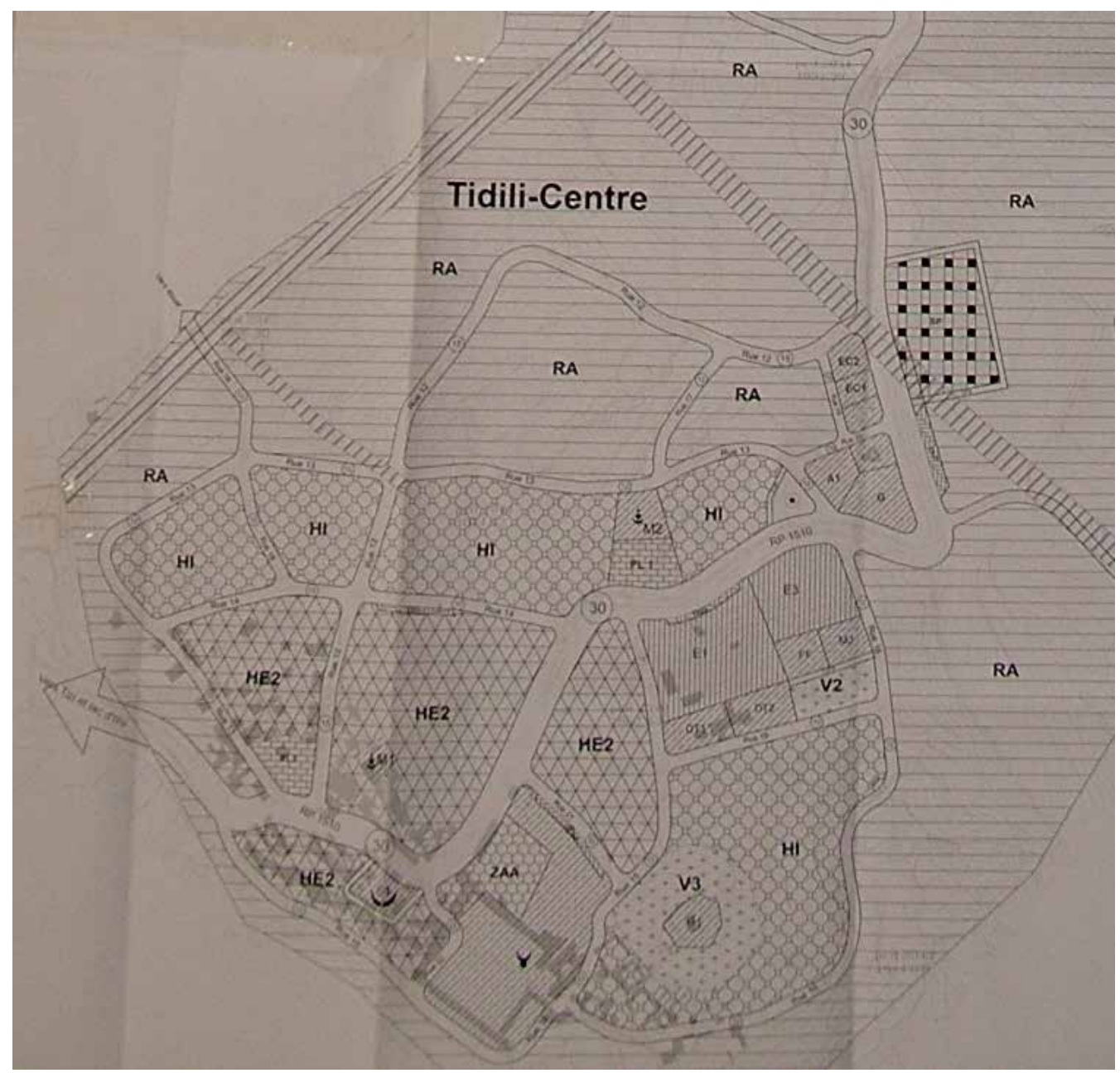

Fot. 7. Plan rozwoju Tidili Centre, 2012. Commune rurale Tidili ...

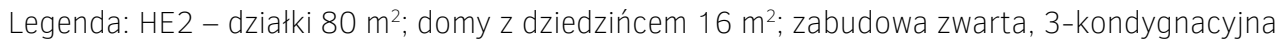
(wys. 11,40 m) ze służebnością podcieni (2 m) dla sklepów; HE1 - działki 80 m², zabudowa zwarta, 2-kondygnacyjna (wys. 8,50 m); HI - strefa ogrodów warzywnych, izolowane siedliska, działki $1000 \mathrm{~m}^{2}$, budynki dwukondygnacyjne; RA - strefa rolnicza, działki $5000 \mathrm{~m}^{2}$; domy dwukondygnacyjne (wys. 8 m); ZAA - obszar działalności rzemieślniczej, pomieszczenia 25 m²

(wys. 4 m); V1, V2, V3 - przestrzeń rekreacyjna, „zielona”; P - parking; PL - Plac; E1, E2, E3 - College, szkoła podstawowa, liceum; DT1, DT2 - internaty dla chłopców, dla dziewcząt; M1, M2 - meczety; A1 - administracja

Ważne funkcje społeczne pełnią dwie kawiarnie oraz plac przed meczetem, gdzie na co dzień zbiegają się ścieżki tutejszych mieszkańców i przybyszy z okolicznych duarów. Cotygodniowy targ - suq, zachował swoją tradycyjną rolę społeczną, sprzężoną z funkcjami kulturowymi, jako przestrzeń dystrybucji wyrobów rzemieślniczych, 
świeżych warzyw, owoców i mięsa, miejsce spotkań, kojarzenia małżeństw, występów wędrownych grajków itp. W kontekście funkcji społecznych osady wspomnieć należy o domie spotkań młodzieży, wybudowanym w stylu tradycyjnej, ufortyfikowanej casby. Budynek będący własnością stowarzyszenia l'Association de bienfaisance islamique d'établissement de protection sociale de Dar Talib et Taliba (Islamskiego Stowarzyszenia Charytatywnego Zakładów Opieki Społecznej Dom Uczniów i Uczennic) symbolizuje otwarcie mieszkańców gminy na ponadlokalne struktury społeczne i kulturalne. Pełni on bowiem między innymi funkcje domu gościnnego dla grup młodzieżowych, goszczących w gminie w ramach różnego rodzaju projektów kulturalnych i rozwojowych ${ }^{25}$.

Inną instytucją gminną, wzmacniającą heterogenny charakter osady Tidili Centre, a przez to wpływająca na tempo i zakres zmian społecznych i kulturowych całej gminy, jest pierwsza w regionie szkoła ponadpodstawowa - college (odpowiednik gimnazjum) nosząca imię Lmokhtar'a Essoussi (fot. 2) ${ }^{26}$. Powstała w 2012 roku, szkoła zatrudnia 38 nauczycieli. Pobiera w niej naukę 325 dzieci, w tym 64 dziewczęta (19,7\% uczniów szkoły) (Carte d'Identité...) ${ }^{27}$. W tym kontekście należy zaznaczyć, że „wysłanie” dzieci, a zwłaszcza dziewczynek do szkoły ponadpodstawowej stanowi poważne wyzwanie logistyczne dla rodzin mieszkających w bardziej odległych osadach. Dystans (w skrajnych wypadkach kilkanaście kilometrów), a zwłaszcza zimowe zaśnieżenie szlaków, wręcz uniemożliwia codzienne dotarcie do szkoły. Taka sytuacja dała asumpt do rozwoju ciekawego zjawiska. Bardziej posażne rodziny (np. przedsiębiorcy budowlani lub transportowi) nie korzystają z internatu, a budują w Tidili Centre dodatkowe domy, w których zamieszkują sezonowo uczniowie college’u (często z młodszym rodzeństwem) pod opieką matki. W weekendy (co w tym wypadku oznacza dzień targowy) dołączają do nich ojcowie i reszta rodziny. Budowa tego typu domów wpływa bezpośrednio na rozrost aglomeracji ${ }^{28}$.

${ }^{25}$ W 2016 roku, został on nieodpłatnie użyczony grupie studentów etnologii UAM w Poznaniu, przebywających tu w ramach warsztatów terenowych.

${ }^{26}$ Imię patrona szkoły jest znamienne w kontekście berberskiego pochodzenia Ait Tidili oraz delikatności kwestii berberskiej w Maroku (Vorbrich 2020). Lmokhtar Essoussi (1900-1963) był Berberem (Amazigh), ale zarazem zwolennikiem tezy o wyższości języka arabskiego i kultury arabskiej, znawcą islamu (sufi), pisarzem i politykiem zasłużonym dla odzyskania niepodległości przez Maroko. Pełnił funkcję ministra do spraw wyznań (1956-1963). Jest zatem wzorem postawy wyrażającej wierność wartościom islamu oraz lojalności Berberów wobec monarchii (Bouskous 1999).

${ }^{27}$ Ta dysproporcja jest nieco mniejsza w ramach szkolnictwa podstawowego i kształtuje się na poziomie 41,4\% dziewczynki oraz 58,5\% chłopcy. Należy dodać w tym miejscu, że na terenie gminy działają 23 jednostki szkolne rozmieszczone na prawie całym jej terytorium. Jednak wskaźnik skolaryzacji (zapisów do szkoły podstawowej) pozostaje w gminie Tidili na drastycznie niskim poziomie i wynosi 37\%, przy wskaźniku 72,5\% w skali całego Maroka i 62,4\% w środowisku wiejskim (Carte d'Identité..., Enseignement primaire...).

${ }^{28} \mathrm{Na}$ rozrost aglomeracji wpływa także zwyczaj budowania tu domów przez emigrantów (pracujących we Francji), dla których będą one „przystanią”, gdy przejdą na emeryturę i wrócą w ojczyste strony. 
College tworzy przestrzeń krzyżowania się heterogennych wzorów kulturowych. Jedne nawiązują do rodzimej kultury berberskiej. Inne odwołują się do (miejskiego pochodzenia) prą̧ów fundamentalizmu muzułmańskiego lub do elementów kultury zachodniej $^{29}$. W konsekwencji można zaobserwować tu zjawisko hybrydyzacji kultury czyli łączenia elementów kulturowych lokalnego pochodzenia z, w sposób wybiórczy przetworzonymi, wzorami importowanymi. W 2013 roku miałem możliwość uczestniczenia w próbie szkolnego teatru, przygotowującego inscenizację sztuki S. Becketta Czekając na Godota. Następnego dnia miałem okazję uczestniczenia w koncercie piosenek berberskich ( $\mathrm{z}$ „hymnem” Ait Tidili: Tifulki Tidili (Ukochane Tidili). Dziewczęta wykonujące te piosenki były jednak ubrane na wzór miejski, z chustami szczelnie zasłaniającymi włosy $(\text { il. } 8)^{30}$.

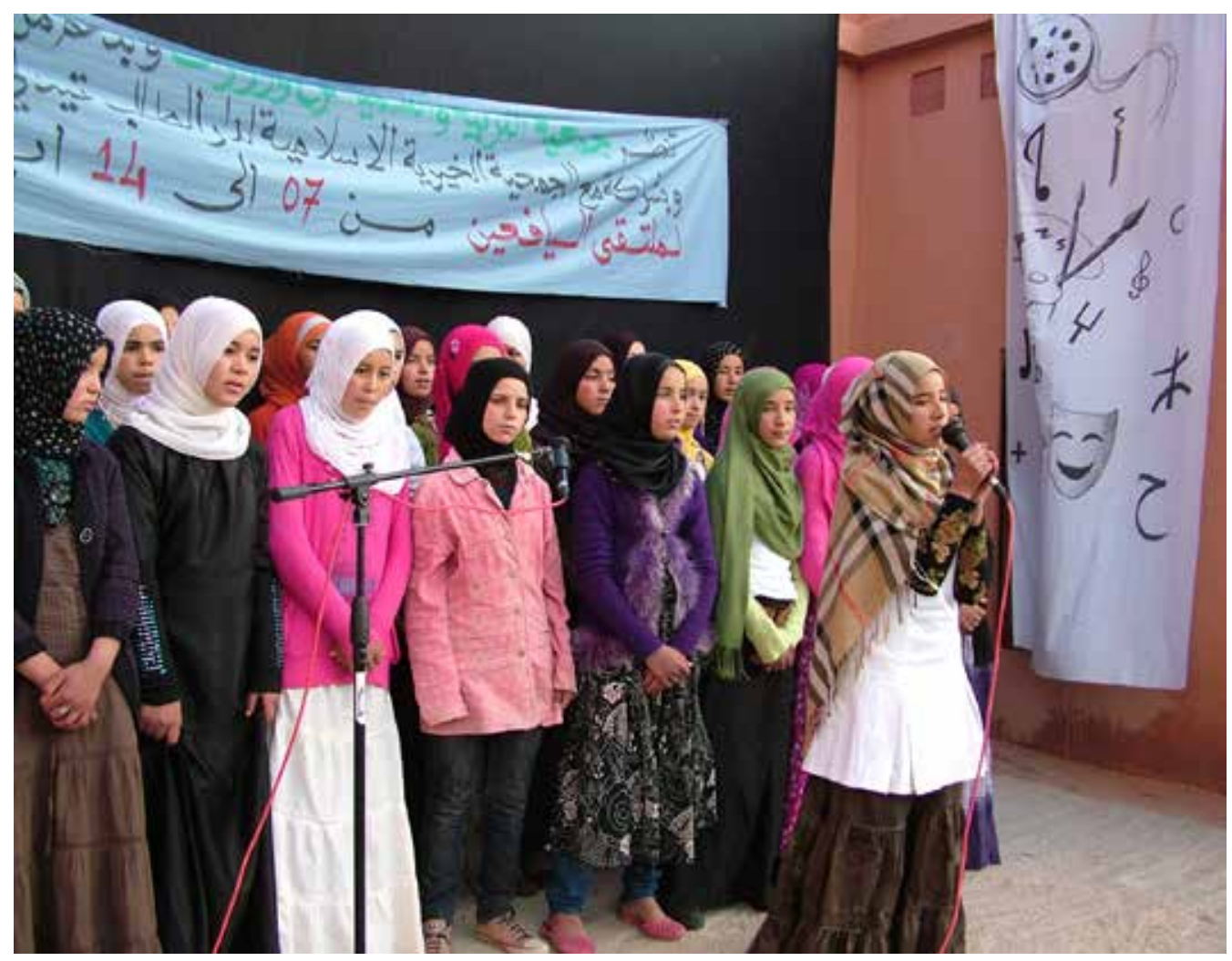

Fot. 8. Uczennice college'u w Tidili Centre, fot. R. Vorbrich 2013

${ }^{29} \mathrm{~W} 2016$ roku, w budynku college'u zorganizowana została wystawa prezentująca dokumentację fotograficzną z 25 lat badań naukowych autora niniejszego studium.

${ }^{30}$ Ich niepiśmienne matki - jako Berberki - jeszcze ćwierć wieku wcześniej nie zakrywały włosów. Co najwyżej, fantazyjnie przewiązane chusty jedynie zdobiły im czubek głowy. 
Omawiana gmina przyjęła obecny kształt terytorialny w 1978 roku, gdy przyłączono do niej peryferyjne tereny, położone wokół Tazoulte-n-Oumradou - dawnego zagłębia górniczego (zob. fot. 4). Obecnie gmina Tidili, jak i inne jej podobne, funkcjonuje według zasad wyznaczonych przez ustawę (dahir no 1-15-85 z 20. dnia ramadanu 1436) z 7 lipca 2015 roku, zawierającą tzw. prawo organiczne (no 113-14), a w jego ramach tzw. Kartę gminy (Charte communale), która daje gminom szeroki zakres kompetencji. Gmina liczy 15285 mieszkańców i obejmuje 48 duarów, podzielonych na cztery frakcje: Ammas, Ait bouyehda waddir, Alighane i Tizgui adekki ${ }^{31}$, przy czym wielkość populacji poszczególnych duarów jest skrajnie różna (od 60 do 760 osób, przeciętnie około 300).

Ustrój gminy ujawnia jej heterogenny charakter, jako niższego poziomu segmentu władzy państwowej - neomaghzenu, a zarazem wyrazu samorządności, nawiązującej do tradycji plemiennej. Kieruje nią zarząd, tworzony przez 17 wybieranych członków (w tym dwie kobiety). Na czele zarządu (Biura) stoi przewodniczący (président), pomaga mu czterech wiceprzewodniczących, sekretarz, zastępca sekretarza i dziesięciu radnych ${ }^{32}$. „Władzę" z wyboru wspiera 16 etatowych urzędników o charakterze merytorycznym bądź technicznym, odpowiedzialnych za funkcjonowanie służb publicznych (Carte d'Identité...). Znacząca część (ponad 50\%) etatowych pracowników urzędu gminy, a także $95 \%$ pracujących na jej terenie nauczycieli nie wywodzi się z Ait Tidili. Potrzeba zapewnienia im odpowiednich warunków mieszkaniowych stanowi troskę władz gminy, a zarazem istotny czynnik stymulujący boom budowlany w Tidili Centre.

Pracownicy etatowi gminy (148 osób w 2020 roku), urzędnicy, personel techniczny i medyczny oraz nauczyciele, wnoszą istotny wkład w poszerzanie wachlarza wzorów kulturowych, zasięgu i charakteru relacji społecznych ogółu mieszkańców gminy, zwłaszcza na terenie jej „stolicy”-Tidili Centre ${ }^{33}$.

W kontekście rozbudowanych funkcji administracyjnych, ekonomicznych i społeczno-kulturowych koncentrujących się w przestrzeni fizycznej Tidili Centre zastanawiać może stosunkowo mała liczba zameldowanych tu na stałe - 77 mieszkańców (2014). W istocie poświadcza to jednak specjalny status osady, jako wielofunkcyjnego i heterogenicznego centrum wspólnoty gminnej. Na stałe mieszka tu niewiele osób

${ }^{31}$ Dane uzyskane bezpośrednio z urzędu gminy.

${ }^{32}$ Wśród członków zarządu gminy 2 osoby są z wykształceniem wyższym, jedna na poziomie średnim, 7 na poziomie podstawowym, a 10 bez formalnego wykształcenia (Carte d'Identité...).

${ }^{33}$ Wzrastająca populacja osób wykształconych w formalnym systemie edukacji, usankcjonowała obecność wszystkich „oficjalnych” języków (berberskiego, arabskiego i francuskiego) w przestrzeni publicznej osady (zob. fot. 9). W kontekście wielojęzyczności warto wspomnieć o zjawisku „berberyzacji”, co najmniej językowej, kobiet (urzędniczek, nauczycielek), które pochodziły z arabskojęzycznych miast, a osiadły w Tidili Centre. Wzory kulturowe cywilizacji islamskiej, kładące nacisk na separacje płci, „skazywały” je (zwłaszcza 20-40 lat temu) na kontakt towarzyski jedynie z Berberkami nieznającymi wówczas języka arabskiego. Mogłem zauważyć, że kobiety te szybciej przyswajały język berberski i „wnikały” w świat tutejszych kobiet. 


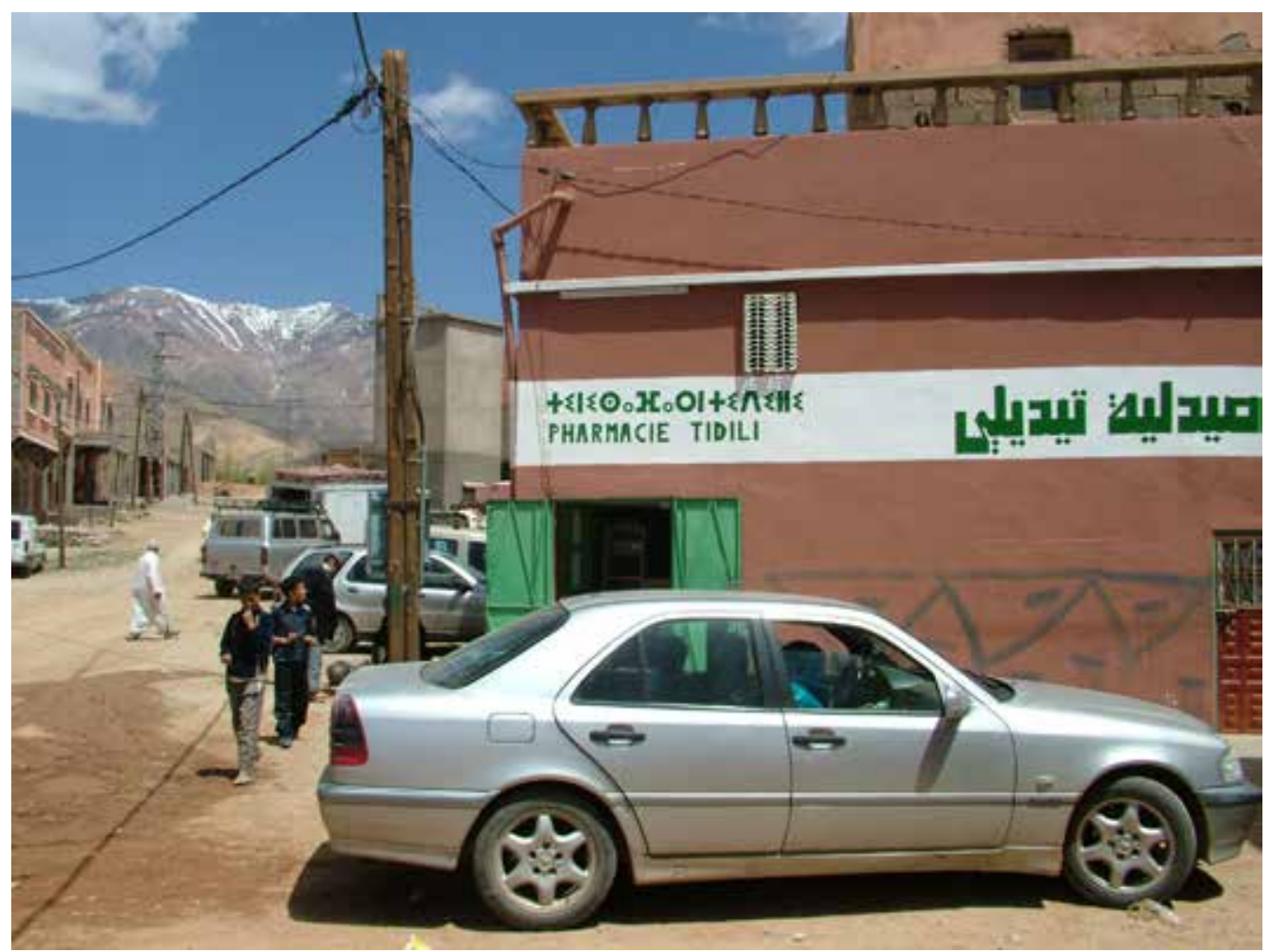

Fot. 9. Ulica centralna w Tidili Centre, szyldy w językach: arabskim, berberskim i francuskim, fot. R. Vorbrich 2013

(nie licząc sezonowych „gości”, w tym uczniów college’u oraz ich rodziców), bowiem „przybysze”, nauczyciele, urzędnicy itp. mieszkają w okolicznych duarach, wynajmując tam mieszkania, pojedyncze pokoje lub we własnych, nowo wybudowanych domach. W ten sposób cztery okoliczne duary, rozlokowane w promieniu $1,5 \mathrm{~km}$, zamieszkałe przez około 2000 osób, przejmują funkcje satelickich osad stolicy gminy, swego rodzaju „sypialni” dla osób zawodowo aktywnych w Tidili Centre.

Za kilka, kilkanaście lat będzie można stwierdzić, w jakim stopniu wspomniany plan rozwoju przyczyni się do konsolidacji przestrzennej osady i wzbogacenia jej o silniejszy komponent o charakterze mieszkalnym, tworząc z Tidili Centre aglomerację małomiasteczkową.

To będzie już jednak doświadczeniem kolejnych pokoleń. Niniejsze studium, nieograniczające się do formuly „etnograficznej fotografii”, odwoływało się do przeszłości, zależnie od dostępnych źródeł, sięgając do początków ubiegłego stulecia lub do doświadczeń żyjących pokoleń (w tym doświadczenia antropologa). Przyjęcie perspektywy procesów długiego trwania pozwoliło nie tylko na uchwycenie kierunku i tempa zmian, ale na wskazanie kluczowych faktów historycznych (braudelowskich „wydarzeń”), 
wyznaczających etapy powstawania protomiejskiej osady Tidili Centre, takich jak: włączenie górskich wspólnot plemiennych w struktury państwa, przeniesienie urzędu gminy $\mathrm{z}$ odległego miasta na teren gminy, wyznaczenie (i infrastrukturalne wyposażenie) plemiennego/gminnego targowiska, przeniesienie urzędu gminy w bezpośrednie sąsiedztwo placu targowego, powstanie gminnych instytucji oświatowych i ochrony zdrowia, a w końcu wybudowanie asfaltowej drogi. Wymienione „wydarzenia”, same w sobie o ograniczonym wymiarze czasowym, wyznaczały jednak, na zasadzie synergii, kierunek procesu.

\section{Bibliografia}

Adam A. 1968. Casablanka.essai sur transformation de la société marocaine au contact de l'Occident. Paris: CNRS.

Ait Hamza M. 2002. Mobilité socio-spatiale et développement local au sud de l'Atlas marocain (Dadès-Todgha), Passau: L.I.S. Verlag.

Ashford D. 1961. Political change in Morocco. Princeton: Princeton University Press.

Benet F. 1957. Explosive Markets: The Berbers Highland. [W:] K. Polanyi (red.), Trade and market in the Early Empires: Economies in History and Theory. Glencoe: Free Press, Glencoe,188-217.

Berriane M. 1997. Emigration Internationale du Travail et Mirco-Urbanisation dans le Rif Oriental: Cas du Centre de Taouim. [W:] Migration Internationale et Changements Sociaux dans le Maghreb. Tunis: Université de Tunis, 75-97.

Boukous A. 1999. Mohammed Mokhtar Soussi, figure emblématique de la difference. [W:] A. Kadri (ed.), Parcours d'intellectuels maghrébins: scolarité, formation, socialisation et positionnements. Paris: Khartala.

Boujrouf S., Hassani E. 2008, Toponymie et recomposition territoriale au Maroc : Figures, sens et logiques. L'Espace politique 2, 40-52.

Braudel F. 1999. Historia i trwanie. Warszawa: Czytelnik.

Emberger L. 1955. Une classification biogéographique des climats. Recueil, travaux de laboratoire géolo-zoologique, Faculté des sciences. Service botanique Montpellier 7, 3-43.

Despois J., Noin D. 1972. La Population rurale du Maroc. Annales de Géographie 81, n444, 248-250.

Dziubiński A. 1983. Historia Maroka. Wrocław: Ossolineum.

Fadloullah A., Berrada A., Khachani M. 2000. Facteurs d'Attraction et de Répulsion des Flux Migratoires Internationaux. Rapport National: Le Maroc. Rabat: Commission Européenne.

Norman D. 1980-81. Les expeditions de Moulay Hassan. Essai statistique. Hesperis-Tamuda 19, 123-152.

Schafar A., Nassori D. 2016. Lacroissance urbaine marocaine: convergence vs concentration. Revue économique 67, 207-226.

Toledano J. 1989. Les Juifs maghrebins. Fils d'Abraham. Bruxelles-Jerusalem: Brepols Col Fils Abraham. 
Troin J.-F. 1975. Les souks Maroccains. Marché ruraux et organization de l'espace dans la moité nord du Maroc. Aix-en-Provence: EDISUD

Vorbrich R. 1996. Górale Atlasu marokańskiego. Peryferyjność i przejawy marginalizacji. Wrocław: PTL.

Vorbrich R. 2015. „Plemię obywatelskie” a monarchia szaryfjiska. Instytucjonalizacja i etatyzacja rozwoju we wspótczesnym Maroku. [W:] A. Żukowski (red.), Komunikowanie w Afryce. Endoi egzogeniczne aspekty. Etnicznośc-kultura-religia. Olsztyn: UWM, 29-52.

Vorbrich R. 2020. Od Berberów do Amazigh. Kultura i Spoteczeństwo 1, 169-196.

Zartman W. J. 1964. Morocco. Problems of New Power. New York: Atherton Press.

\section{Źródła}

Carte d'Identité Territotial de la Commune Rurale de Tidili b.d. m.w., dokument gminy Tidili

Commune rurale Tidili 2012. [in:] Plan de developpement du centre de Tidili, dokument gminy Tidily.

\section{Źródła internetowe}

Alphabetisation au Maroc plan d'action 2012-2015, http://www.unesco.org/new/fileadmin/ MULTIMEDIA/HQ/ED/pdf/Maroc.pdf, 01.03.2021

Gandini, J. 2016, Affaires indigènes. Lofficier des Affaires Indigènes, https://www.ouarzazate-1928-1956.fr/armee/affaires-indigenes/92-lofficier-des-affaires-indigenes.html, 20.01.2020.

Enseignement primaire: Hausse significative de la scolarisation des enfants, https://fnh.ma/article/ actualites-marocaines/enseignement-primaire-hausse-significative-de-la-scolarisation-des -enfants, 02.03.2021.

Tidili Centre. Zdjęcie satelitarne, Google Earth, https://www.google.com/maps/place/ Maroko/@31.1000774,-7.6088923,479m/data=!3m1!1e3!4m5!3m4!1s0xd0b88619651c58d:0xd9d39381c42cffc3!8m2!3d31.791702!4d-7.09262, 16.08.2020

Autor:

Prof. dr hab. Ryszard Vorbrich

e-mail: vorbrich@amu.edu.pl 
